\title{
On the Cultural Untranslatability in Chinese-English Literary Translation
}

\author{
MENG Dou-dou, WANG Jing \\ Zhuhai College of Jilin University, Zhuhai, China
}

\begin{abstract}
The paper is intended to study the cultural untranslatability in Chinese-English literary translation and its compensation with a view to find some practical strategies in translation when untranslatabiltiy occurs. Based on Eugene A. Nida's classification of language culture, the author analyzes causes of cultural untranslatability in terms of ecological culture, material culture, social culture, religious culture, and linguistic culture through specific examples. As the cultural untranslatability is conditioned, variable, and dynamic, some translation strategies are proposed for tranferring untranslatability to translatability.
\end{abstract}

Keywords: translatability, untranslatability, cultural untranslatability, Chinese-English translation

\section{Introduction}

What is untranslatability? It refers to the fact that the content and form of a source text cannot be simultaneously and adequately conveyed in the translation. As each language has its own uniqueness, it is difficult to translate this uniqueness into another language, which brings about untranslatability. The controversy of translatabilty and untranslatabilty has long been receiving attention from scholars in translation studies. This paper mainly discusses the cultural untranslatability in translating Chinese literary works into English and explores the strategies of the possible dynamic transfer from untranslatability to translatabilty.

\section{The Paradox of Translatabilty and Untranslatability}

Translatabilty is a term used to discuss "the extent to which it is possible to translate either individual words and phrases or entire texts from one language to another" (Shuttleworth \& Cowie, 2004, p. 179). It is one of the fundamental problems in translation studies. In translation, when the content and form of the source language cannot be simultaneously and adequately conveyed in the target language, some elements of the source language may be lost. In this sense, these elements are untranslatable. To put it simply, translatabiltiy refers to the possibility of converting the source language into the target language, while untranslatabilty refers to the impossibility or the limits of this conversion. In fact, in the process of translation, translatability and untranslatability coexist in the text. It depends on how much the forms and meanings of the original texts are reproduced in the target texts and how much they are lost. The more the forms and contents of source texts are

MENG Dou-dou, Department of Foreign Languages, Zhuhai College of Jilin University, Zhuhai, China. WANG Jing, Department of Foreign Languages, Zhuhai College of Jilin University, Zhuhai, China. 
reproduced, the more translatabilty the text has; the more the forms and contents of source texts are lost, the more untranslatability the text has.

As the law of the unity of opposites is the fundamental law of the universe, everything is dialectically unified, so translatability and untranslatability are also a dialectical unity, which coexist in translation. There is no absolute translatability, nor absolute untranslatability.

When we review the whole history of the controversy about translatability and untranslatablity, it can be seen that the discussion and research falls into two main stages: In the primary stage, scholars focused their attention on the possibility of translation. However, with the development of translation, scholars have shifted their attention to the degree of translation. A consensus has been reached that translation is possible, but translatability is limited, for in the process of translation the loss of information is inevitable.

The existence of untranslatability is not based on the negation of translatability, and the existence of translatability does not fundamentally negate the premise of untranslatability. To a certain extent, translatabiltiy and untranslatability are complementary. Some scholars even refer to "untranslatability" as the "limits of translation”.

\section{Causes and Categories of Cultral Untranslatability}

According to J. C. Catford (1965, p. 93), an English linguist and translator, "Translation fails—or untranslatability occurs-when it is impossible to build functional features of the situation into the contextual meaning of the target language text”. Based on the causes of untranslatability, he classified untranslatability into "linguistic untranslatability" and "cultural untranslatability" in his A Linguistic Theory of Translation. Linguistic untranslatability occurs when there is no lexical or syntactical substitute in the target language for a source language item, whereas cultural untranslatability is due to the absence in the target language culture of a relevant situational feature for the source language text. He believed that cultural untransalatability was less absolute than linguistic untranslatabiltiy.

Eugene A. Nida (2001, p. 82) once divided language-culture into ecological culture, material culture, social culture, religious culture, and linguistic culture. In his opinion, linguistic features of a certain language are part of its culture. In the following part, we will focus on the cultural untranslatability in Chinese-English literary translation in terms of the ecological culture, the material culture, the religious culture, the material culture, and the linguistic culture.

\section{Untranslatability Due to the Ecological Culture}

The ecological culture of a nation is influenced by its regional features, natural conditions, and geographical environments. The ecological conditions, which are manifested in animals, plants, climates, terrains, and so on, vary from region to region or from country to country. The ecological conditions will inevitably affect the cultures of all ethnic groups, giving the culture a distinct regional character. With the impact of its special ecological culture, Chinese has a lot of special culture-loaded words and terms, for which there are no equivalents in English. For instance, “泰山北斗” and “付诸东流” embody peculiar geographic features in China and it is quite hard to render them into English. “东风” and "east wind” have the same literal meaning but different cultural connotations. In Chinese culture, “东风” indicates warmth and spring, while in British culture, "east wind" indicates coldness and unhappiness. This is determined by the differences in the geographical 
environments. If readers and translators know little about this cultural connotation, the information of the source language will be lost in the process of translation.

\section{Untranslatability Due to the Material Culture}

The imbalance in the development of material culture in the world causes differences in material civilizations between countries, regions, and nations. All these differences are reflected in their respective languages, which bring difficulties to translation. For instance, it is difficult to translate “喝酒” into English, for there is liquor, spirit, alcohol, drink, beer, wine, and so on in English, each of which has its own emphasis and reference.Taking Chinese diet culture as an example, there are more than 30 cooking methods: “煎, 炒, 烹, 炸, 酥, 溜, 炝, 煸, 鰲, 烩, 卤”, and so on, whereas the methods of cooking in the west are relatively simple and limited. Because of these cultural differences, many Chinese cooking methods cannot be translated into English.

\section{Untranslatability Due to Religious Culture}

There are three major religions in China: Confucianism, Taoism, and Buddhism, which are quite different from Christianity and Catholicism in the Western culture. The difference of religions between different cultures would be directly and indirectly reflected in people's language and communication, causing untranslatablity. Take “三清观”, which refers to a typical temple in Taoism, as an example, “三清观” is a temple dedicated to the three most respected and highest gods in Taoist pantheon, who are known as Three Pure Ones. If “三清观” is rendered into "Taoist Temple", the cultural connotation is lost in the translation.

\section{Untranslatability Due to the Social Culture}

Social culture consists of the values, interpersonal relationships, political and economic relations, traditional concepts, customs, and habits of a nation or society. Rich cultural heritage is contained in the history of a nation or society, which serves as the record of its development. In the long history of China, a great number of allusions and idioms have been formed, many of which originated from historical events, myths, legends, and literature masterpieces. When they are rendered into English, it is possible to bring about the loss of the cultural information and cultural connotation.

See Example (1)-(3):

(1) 事后诸葛亮 to be wise after the event

(2) 名落孙山 not in the name-list of the successful candidate

(3) 四面楚歌 in a besieged and dangerous situation

From the above examples, it can be found that although the translated version has reproduced the meaning of the source text, it has lost the historical cultural connotation of the source text: “诸葛亮” in the Three Kingdoms period is the incarnation of wisdom and there are allusions about “孙山” and “四面楚歌”.

Chinese has a lot of appellations based on kinship, such as “伯父”, “叔父”, “姑父”, “姨父”, “堂哥”, “堂弟”, “表哥”, and “表弟”, while in English uncles and cousins are used to refer to all those above-mentioned Chinese appellations. For example, “表哥”, in Chinese refers to one’s male cousin on mother’s side older than oneself. “表哥” and “cousin” are not culturally equivalent. 


\section{Untranslatability Due to the Linguistic Culture}

Languages have their own unique phonetic, lexical, and syntactic features. When these language features are supposed to be conveyed as significant information in translation, the translatability is restricted as a result of the differences in the linguistic culture between the source language and the target language. There is no information conversion channel for the linguistic forms, such as sounds and graphemes between Chinese and English. Sounds and pronunciations in Chinese are often used to fulfill certain rhetoric effect, which leads to untranslatability.

See Example (4)-(6):

(4) 您别拾起来棒来一当针 (真)

(5) 外甥打灯笼一照舅 (旧)

(6) 小葱拌豆腐一一青二白 (清)

In the above examples, there are three "Xiehouyu", a two-part allegorical saying only existing in Chinese, of which the first part, always stated, is descriptive, while the second part, sometimes unstated, carries the message. All of them cannot be translated into English, for there are no associations between "needle" and "being serious", between "uncle” and "as usual”, and between "green” and "pure” in English.

\section{Strategies for Transferring Untranslatabilty to Translatability}

In Theoretical Problems on Translation, Georges Mounin (1963) demonstrated that translation is possible but it does have limits, which provides a theoretical basis for the dynamic transformation of untranslatability. It is believed that untranslatability in language is absolute, while cultural untranslatability is relative. Under specific conditions, cultural untranslatability can be transferred into translatability. The transformation of untranslatability requires the translators to adopt some effective and creative means or strategies to turn something untranslatable into something translatable, decreasing the loss of information of the source text in the process of translation. When untranslatability occurs, we can trace back to the differences of source language and target language, exploring their linguistic and cultural background and disparities so as to transfer untranslatabilty to translatability.

\section{Finding Substitution in the Target Language}

If a completely equivalent expression cannot be found in the target language, a similar one can be used to compensate for the loss of information in the translation.

See Example (7)-(11):

(7) 浑水摸鱼 fish in troubled water

(8) 轻如鸿毛 as light as feather

(9) 眼见为实 seeing is believing

(10) 雨后春笋 to sping up like mushrooms

(11) 挥金如土 to spend money like water.

\section{Adopting Semantic Domestication}

Domestication means bringing the foreign culture closer to the target culture, making the text intelligible and familiar, as is said by Andre Lefevere "whatever is strange, different or other has to be naturalized into the target language and culture so that it is immediately understandable”. 
See Example (12):

(12) 千万不要板门弄斧 Never offer to teach fish to swim

Lu Ban, the master carpenter, whom English readers know little about, is well-known in China. If the sentence is translated into "Never show off your proficiency with the axe before Lu Ban", readers will be confused. The adoption of semantic domestication makes English readers understand the sentence easily.

\section{Seeking Functional Equivalence}

Functional equivalence or dynamic equivalence is introduced by Nida, referring to the quality which characterizes a translation in which, "the message of the original text has been so transported into the receptor language that the response of the receptor is essentially like that of the original receptors" (Shuttleworth \& Cowie, 2004, p. 47). The purpose of the source language is to be considered first in translation rather than the content or the form. Faithfulness to the source language is function-oriented not form-oriented. Eugene A. Nida, the famous American linguist, maintained translation means translating meaning (Ward \& Nida, 1986, p. 60)

See Example (13):

(13) 我姓王, 三横一坚的王 My family name is WANG, W-A-N-G

It is difficult to translate the original text into English, for it conveys the visual image of the Chinese character “王”. Transferring the visual image of “王” to “W-A-N-G” in the translation has achieved the same function of explaining the family name visually.

\section{Using the Method of Footnote}

A footnote is a note of reference or explanation at the foot of the paper if necessary, which is a form of interpretation. Through footnote, the background information which does not exist in target language is provided. The method of adding a footnote can make up for the missing cultural information of the original text in translation.

See Example (14):

\section{(14) 姜太公钓鱼, 愿者上钩}

Chiang Taikung finshes to capture those who want to be caught

In the above example, the receptors of the translation must wonder who Chiang Taikung is with little knowledge about the allusion behind it. In order to make readers clear about the allusion, adding footnote is necessary and effective: Chiang Ziya was said to fish by the Weishui River. He held a line, with no hook or bait, three feet above the water, saying to the fish: "Come and take the bait".

\section{Conclusion}

Language serves as not only the component but also the carrier of culture, being an important means of cultural inheritance and transmission. Every language contains its own cultural deposits and marks. Translation is not only the conversion between languages but also the exchange between cultures. There are great differences between Chinese and English in terms of ecological culture, material culture, social culture, religious culture, and linguistic culture, which brings tremendous changes to Chinese-English translation and leads to cultural untranslatability. The cultural untranslatability is conditioned, variable, and dynamic, which means untranslatability can be transferred into translatability through using some strategies. Just as Walter Benjamin 
once said that translation is a kind of creative artistic activity, translators should try their best to demonstrate the translatability of the original text and thus gives the original text "an after-life".

\section{References}

Biguenet, J., \& Schulte, R. (1989). The craft of translation. Chicago: The University of Chicago Press.

Catford, J. C. (1965). A linguistic theory of translation. Oxford: Oxford University Press.

Liu, M. Q. (1999). Contemporary translation theory. Beijing: China Translation and Publishing Corporation.

Mounin, G. (1963). Les problems theoriques de la traduction (Theoretical problems on translation). Paris: Gallimard.

Newmark, P. (2001). A textbook of translation. Shanghai: Shanghai Foreign Language Education Press.

Nida, E. A. (2001). Language and culture: Contexts in translating. Shanghai: Shanghai Foreign Language Education Press.

Shuttleworth, M., \& Cowie, M. (2004). Dictionary of translation studies. Shanghai: Shanghai Foreign Language Education Press. 